\title{
Atypical presentation of burrowing bug pigmentation involving a non-acral site
}

\author{
Dibyendu Bikash Bhanja, ${ }^{1}$ Abheek Sil, ${ }^{1}$ Atanu Chandra 지, ${ }^{2}$ Uddalak Chakraborty iㅇ ${ }^{2}$
}

${ }^{1}$ Dermatology, Venereology, Leprosy, RG Kar Medical College and Hospital, Kolkata, West Bengal, India

${ }^{2}$ Internal Medicine, RG Kar Medical College and Hospital, Kolkata, West Bengal, India

\section{Correspondence to} Dr Atanu Chandra; chandraatanu123@gmail.com

Accepted 4 February 2021

Check for updates

(c) BMJ Publishing Group Limited 2021. No commercial re-use. See rights and permissions. Published by BMJ.

To cite: Bhanja DB, Sil A, Chandra A, et al. BMJ Case Rep 2021;14:e241792. doi:10.1136/bcr-2021241792

\section{DESCRIPTION}

A 31-year-old farmer hailing from a rural village of Eastern India presented with asymptomatic pigmented skin eruptions over chest for the last 2 days. Prior to the appearance of the skin lesions, he was busy working sowing paddy seeds during the rainy season. He had no history of associated fever, cough, joint pain, preceding trauma, drug intake or any contact with exogenous chemicals. Few other farmers in his village had also developed similar skin lesions over exposed body parts, which had resolved on their own without any medical intervention. Examination revealed multiple, scattered, non-blanchable, irregularly shaped brownish-black macules $(2-4 \mathrm{~mm}$ in diameter) with streaky ends resembling lentigines, distributed over anterior chest (figure 1). The pigmented macules could not be wiped off using water, soap or acetone. Other mucocutaneous sites were uninvolved and systemic examination was unremarkable. Basic laboratory investigations were unremarkable. The skin lesions resolved on their own after 1 week without any residual changes. Based on sudden appearance of characteristic pigmentation, clustering of cases in the rainy season, spontaneous resolution, along with the history of being involved in outdoor activity clinched the diagnosis of burrowing bug pigmentation.

Cydnidae bug, also called as burrowing or burrower bug, are arthropods of the order Hemiptera, and are usually found in rural areas in the fields during monsoon months. They are recognised by the morphological adaptations for digging. ${ }^{1}$ They borrow in soil or sand and feed on roots or other underground parts of plants and are not routinely accessible. A hydrocarbonate (odorous substance) is produced from their special glands located in thorax (in adult) and abdomen (in nymph) that acts as a repellent and chemoattractant. ${ }^{2}$ This substance is responsible for the sudden onset of asymptomatic pigmented macules resembling lentigines at the site of contact on accidental crushing or pressure on the insects. ${ }^{3}$ Contrary to true lentigines, burrowing bug pigmentation particularly occurs during rainy season and spontaneously resolves within 1-2 weeks. Although there is a predilection for involvement of acral areas, appearance of pigmentation over the trunk has rarely been described. ${ }^{45}$ Dermoscopy is a useful bedside tool to differentiate this benign self-resolving pigmentation from other mimickers, including eruptive lentigines, junctional melanocytic nevi, petechiae of dengue fever and exogenous pigmentation due to chemical contact. Dermoscopic features described

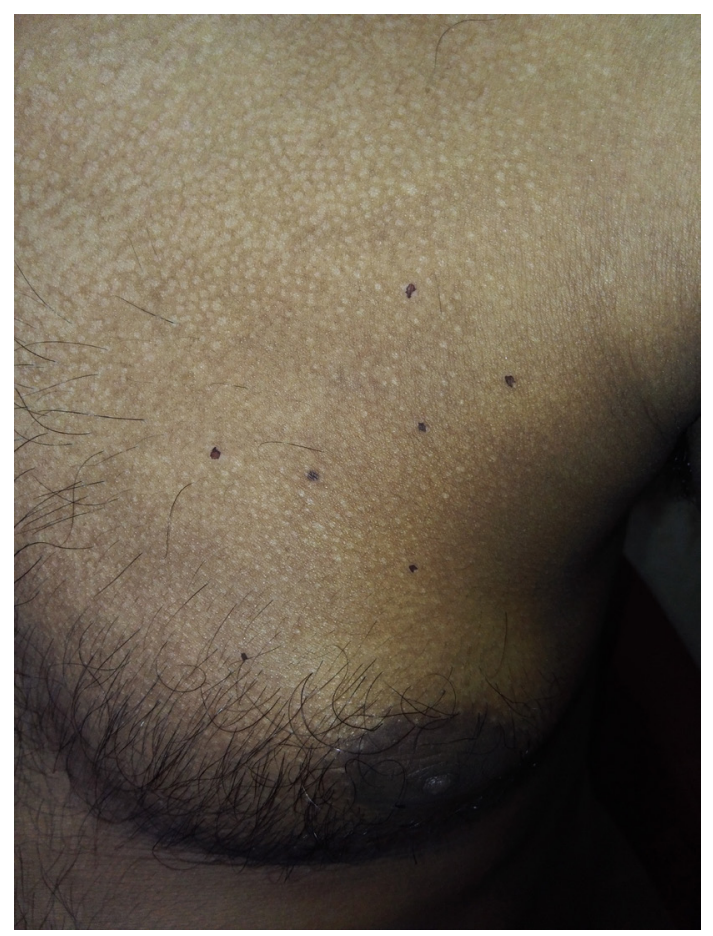

Figure 1 Multiple discrete, irregularly shaped brownishblack macules resembling lentigines distributed over the chest.

in burrowing bug pigmentation include homogeneous brown-black pigmentation, frayed parallel furrows and accentuation of pigmentation around the sweat glands. ${ }^{15}$ Sudden onset and characteristic pigmentation on exposed body parts in the rainy season with spontaneous resolution are important clinical pointers towards the diagnosis of burrowing bug pigmentation.

Physicians should be aware of this newly recognised and uncommon cause of exogenous pigmentation to avoid unnecessary interventions.

\section{Learning points}

Sudden onset lentigines - like pigmentation during monsoon season over exposed body sites (predominantly acral areas) — in a patient engaged in outdoor activity should raise the suspicion of burrowing bug pigmentation. However, non-acral areas like the trunk, neck and face may rarely be involved.

- Burrowing bug pigmentation is a self-resolving condition. 
Adequate counselling about the self-resolving nature of the condition will alleviate fear and anxiety of the patient.

Contributors DBB and AS contributed to the conception, initial drafting of the manuscript, critical revision of content and final approval of manuscript. DBB, UC and $A C$ contributed to patient management, conception, critical revision of content and final approval of the manuscript. All authors are in agreement to be accountable for all aspects of the work in ensuring that questions related to the accuracy or integrity of any part of the work are appropriately investigated and resolved.

Funding The authors have not declared a specific grant for this research from any funding agency in the public, commercial or not-for-profit sectors.

Competing interests None declared.

Patient consent for publication Obtained.

Provenance and peer review Not commissioned; externally peer-reviewed.

\section{ORCID iDs}

Atanu Chandra http://orcid.org/0000-0002-3809-8926

Uddalak Chakraborty http://orcid.org/0000-0002-1691-6289

\section{REFERENCES}

1 Batrani M, Kubba A, Ramam M. A curious case of vanishing pigmented spots resembling lentigines. Indian I Dermatopathol Diagn Dermatol 2019;6:42-4.

2 Hosokawa T, Kikuchi Y, Nikoh N, et al. Polyphyly of gut symbionts in stinkbugs of the family Cydnidae. Appl Environ Microbiol 2012;78:4758-61.

3 Malhotra AK, Lis JA, Ramam M. Cydnidae (burrowing bug) pigmentation: a novel arthropod dermatosis. JAMA Dermatol 2015;151:232-3.

4 Chakraborty S, Sil A, Panigrahi A. Burrowing bug pigmentation. Infection 2020;151. doi:10.1007/s15010-020-01481-w. [Epub ahead of print: 11 Jul 2020].

5 Agarwal R, Srinivas S, Chandrashekar BS. Asymptomatic freckle-like hyperpigmentation of the palms: A rare pigmentation caused by cydnidae (burrowing bug). Indian 」 Paediatr Dermatol 2019;20:353-4.

Copyright 2021 BMJ Publishing Group. All rights reserved. For permission to reuse any of this content visit

https://www.bmj.com/company/products-services/rights-and-licensing/permissions/

BMJ Case Report Fellows may re-use this article for personal use and teaching without any further permission.

Become a Fellow of BMJ Case Reports today and you can:

- Submit as many cases as you like

- Enjoy fast sympathetic peer review and rapid publication of accepted articles

- Access all the published articles

Re-use any of the published material for personal use and teaching without further permission

\section{Customer Service}

If you have any further queries about your subscription, please contact our customer services team on +44 (0) 2071111105 or via email at support@bmj.com.

Visit casereports.bmj.com for more articles like this and to become a Fellow 